\title{
Factors Influencing Touristic Demand Analysis on Glagah Beach as Tourism Object on Kulon Progo Regency
}

\author{
Mohamad Halimi ${ }^{1}$, Rr. Fosa Sarassina ${ }^{2}$ \\ 1,2Prodi Manajemen, Departemen Ekonomika dan Bisnis \\ Sekolah Vokasi UGM, Indonesia. \\ Email: halimi@ugm.ac.id \\ Email: Fosa.sarassina@ugm.ac.id
}

\begin{abstract}
The purpose of this study was to determine the factors that influence tourist demand for Glagah Beach tourism objects in KulonProgo Regency. This research is quantitative research. Data collection used in the study was carried out through questionnaires. The population in this study are all visitors who come to the Glagah Beach tourism object. Taking into the large number of populations that are not known with certainty, then in this study 100 samples were taken. The selected respondents were visitors to the Glagah Beach tourism object who also visited Congot Beach and Kiskendo Goa attractions, both after visiting Glagah Beach and before visiting Glagah Beach. Sampling is done through accidental sampling. Data analysis was performed through multiple regression analysis with the $F$ test, $t$ test, determination test. The results showed that the cost of travel to Glagah Beach tourism objects, the cost of travel to other attractions, and income per month have negative influence to the number of beach tourism objects Glagah, the other hand, Age and Distance variables have positive influence to the number of beach tourism objects Glagah. From this research just Cost of Travel to Glagah Beach tourism objects that influence tourist demand for Glagah Beach Significantly. The contribution of this research is to increase tourist demand for Glagah Beach in KulonProgo Regency.
\end{abstract}

Keywords: touristic demand, tourist destinations, tourism object, Glagah Beach.

\section{PENDAHULUAN}

Objek Wisata Pantai Glagah di Temon Kulon Progo Yogyakarta adalah salah satu "primadona" tempat wisata yang berada di Desa Glagah, Kecamatan Temon, Kabupaten Kulon Progo, Daerah Istimewa Yogyakarta, Indonesia. Objek Wisata Pantai Glagah adalah tempat wisata yang ramai dengan wisatawan pada hari biasa maupun hari liburan. Tempat ini sangat indah dan bisa memberikan sensasi yang berbeda dengan aktivitas sehari-hari.

Objek Wisata Pantai Glagah di Temon Kulon Progo Yogyakarta memiliki pesona keindahan yang sangat menarik untuk dikunjungi. Objek Wisata Pantai Glagah di Temon Kulon Progo Yogyakarta merupakan primadona di Kulonprogo. Di pantai ini pengunjung dapat bermain kano di laguna, naik motorcross di hamparan pasir besi, memancing di atas tetrapod yang berfungsi sebagai pemecah ombak, hingga memetik buah naga di agrowisata.Berbeda dengan pantai-pantai di Gunungkidul yang dibatasi bukit karang, tepian Pantai Glagah terlihat sangat panjang tanpa penghalang. Sejauh mata memandang yang terlihat adalah hamparan pasir besi kehitaman. Ombak di Pantai Glagah terbilang cukup besar. Karena itu di kawasan pantai ini dibangun sebuah dermaga panjang dengan tetrapod di kanan kirinya. Tetrapod tersebut berfungsi sebagai pemecah ombak.

Penelitian ini dilakukan untuk menganalisis faktorfaktor yang mempengaruhi permintaan obyek wisata Pantai Glagah dan mengukur nilai ekonomi obyek wisata Pantai Glagah dengan menggunakan Travel Cost Method (TCM). Faktor-faktor yang mempengaruhi permintaan obyek wisata Pantai Glagah antara lain biaya perjalanan ke obyek wisata Pantai Glagah.

Biaya perjalanan akan mempengaruhi wisatawan berkunjung ke obyek wisata, khususnya obyek wisata Pantai Glagah. Semakin besar biaya yang dikeluarkan oleh wisatawan untuk berkunjung ke obyek wisata, maka permintaan terhadap obyek wisata tersebut akan berkurang. Sedangkan apabila biaya perjalanan yang dikeluarkan semakin kecil, maka permintaan terhadap obyek wisata tersebut akan semakin besar.

Pendapatan per bulan merupakan faktor penting dalam membentuk permintaan wisatawan untuk mengadakan perjalanan wisata. Pendapatan per bulan seseorang akan berperan dalam pengambilan keputusan dalam memilih obyek wisata yang akan dikunjunginya. Jarak merupakan salah satu faktor yang menentukan wisatawan untuk melakukan rekreasi. Semakin jauh tempat tinggal seseorang dari tempat obyek wisata, maka permintaan terhadap obyek wisata tersebut semakin rendah dan sebaliknya wisatawan yang tempat tinggalnya berdekatan dengan obyek wisata tersebut, maka permintaan terhadap obyek wisata tersebut akan semakin tinggi.

Umur secara tidak langsung dapat mempengaruhi permintaan wisatawan untuk berkunjung ke obyek wisata. Karena umur berkaitan dengan waktu luang dan aktifitas serta kemampuan wisatawan untuk melakukan kunjungan wisata. Selain faktor-faktor di atas, pengunjung juga mempertimbangkan biaya perjalanan ke obyek wisata lainnya, waktu luang, pengalaman berkunjung sebelumnya dan tujuan berkunjung dalam memilih obyek wisata yang dikunjungi. Biaya perjalanan ke obyek wisata lain adalah biaya perjalanan ke obyek wisata komplementer dan subtitusi. Obyek wisata komplementer dari Pantai Glagah adalah Pantai Congot. Sedangkan obyek wisata substitusi Pantai Glagah adalah Goa Kiskendo.

Pengalaman berkunjung sebelumnya ke obyek wisata Pantai Glagah dapat dipengaruhi oleh selera dan preferensi pengunjung terhadap permintaan pariwisata ke obyek wisata Pantai Glagah dan obyek wisata lainnya. Sedangkan tujuan berkunjung menjadi faktor 
pendorong seseorang untuk melakukan suatu tindakan dalam mencapai tujuan yang diinginkan, begitu pula dengan pengunjung obyek wisata Pantai Glagah. Diharapkan dengan menggunakan Travel Cost Method (TCM) akan didapatkan nilai ekonomi yang mendekati nilai sebenarnya, sehingga dapat dijadikan acuan bagi pemerintah Daerah Kabupaten Kulon Progo dalam menentukan arah kebijakan terkait obyek wisata Pantai Glagah.Uraian yang telah dijelaskan sebelumnya menunjukkan bahwa permintaan terhadap obyek wisata dipengaruhi oleh beberapa faktor. Berdasarkan latar belakang tersebut maka perlu dilakukan penelitian dengan fokus penelitian: "Analisis Faktor yang Mempengaruhi Permintaan Wisata pada Objek Wisata Pantai Glagah di Kabupaten Kulon Progo".

\section{METODE PENELITIAN}

Penelitian ini adalah penelitian kuantitatif. Pengumpulan data yang digunakan dalam penelitian ini dilakukan melalui kuesioner. Populasi dalam penelitian ini adalah semua pengunjung yang datang ke objek wisata Pantai Glagah. Dengan mengambil jumlah besar populasi yang tidak diketahui dengan pasti, maka dalam penelitian ini diambil 100 sampel. Responden yang dipilih adalah pengunjung ke objek wisata Pantai Glagah yang juga mengunjungi objek wisata Pantai Congot dan Goa Kiskendo, baik setelah mengunjungi Pantai Glagah dan sebelum mengunjungi Pantai Glagah. Pengambilan sampel dilakukan melalui accidental sampling. Analisis data dilakukan melalui analisis regresi berganda dengan uji $\mathrm{F}$, uji t, uji determinasi.

\section{HASIL DAN PEMBAHASAN Analisis Regresi}

Analisis regresi linier berganda merupakan analisis yang dilakukan untuk mengetahui adanya pengaruh antara variabel bebas terhadap terikat. Dalam hal ini, analissi regresi dilakukan untuk mengetahui faktor-faktor yang berpengaruh jumlah permintaan obyek wisata Pantai Glagah. Untuk lebih jelasnya mengenai analisis regresi, maka dapat dilihat pada tabel koefisien regresi berikut ini.

\begin{tabular}{|c|c|c|c|c|}
\hline Variabel & Koefisien Regresi & Standardized Coefficients & t hitung & Sig \\
\hline Konstanta & 2,200 & - & 3,686 & 0,000 \\
\hline Biaya Perjalanan ke Pantai Glagah (X1) & $-0,143$ & $-0,314$ & $-2,164$ & 0,033 \\
\hline Biaya Perjalanan ke Obyek Wisata Lain (X2) & $-0,016$ & $-0,057$ & $-0,561$ & 0,576 \\
\hline Umur (X3) & 0,062 & 0,060 & 0,408 & 0,684 \\
\hline Pendapatan per Bulan (X4) & $-0,039$ & $-0,110$ & $-0,664$ & 0,508 \\
\hline Jarak (X5) & 0,012 & 0,027 & 0,225 & 0,823 \\
\hline
\end{tabular}

Jarak $(X 5)$

F hitung $=2,777$, P-value $=0,022$

Sumber: data diolah (2019)

Dari tabel di atas, maka dapat disusun persamaan linier dari variabel-variabel yang mempengaruhi permintaan objek wisata sebagai berikut :

$$
Y=2,200-0,143 X 1-0,016 X 2+0,062 X 3-0,039 X 4+0,012 \times 5
$$

Berdasarkan persamaan di atas dapat diketahui bahwa faktor yang berpengaruh positif terhadap permintaan wisata Pantai Glagah adalah umur dan jarak tempuh. Faktor yang berpengaruh negatif adalah biaya perjalanan ke Pantai Glagah, biaya perjalanan ke objek wisata lain, dan pendapatan per bulan.

\section{Uji Statistik}

1 Uji Determinasi

Koefisien determinasi atau Coefficient of Determination $\left(\mathrm{R}^{2}\right)$ mengukur jumlah proporsi (bagian) atau prosentase total variasi dalam $Y$ yang dapat dijelaskan oleh model regresi.Dengan kata lain bahwa uji ini dilakukan untuk mengetahui besarnya variansi atau determinasi dari variabel biaya perjalanan ke Pantai Glagah (X1), biaya perjalanan ke obyek wisata lain (X2), umur (X3), pendapatan per bulan (X4), jarak (X5) yang mampu mempengaruhi permintaan objek wisata Pantai Glagah.

Hasil pengujian $\mathrm{R}^{2}$ dapat dilihat pada Tabel 1 sebelumnya. Nilai Koefisien Determinasi $\left(R^{2}\right)$ sebesar 0,129 mempunyai arti bahwa variabel terikat $Y$ dipengaruhi oleh variabel bebas sebesar 12,9\%, sedangkan sisanya sebesar $87,1 \%$ dipengaruhi oleh faktor-faktor lain diluar model, yang tidak diperhitungkan dalam penelitian ini.

2 Uji F

Uji $F$ dilakukan untuk mengetahui adanya pengaruh yang signifikan atau tidak antara variabel bebas secara bersama-sama terhadap variabel terikat. Uji nilai ini digunakan untuk melihat adanya pengaruh dari biaya perjalanan ke Pantai Glagah (X1), biaya perjalanan ke obyek wisata lain (X2), umur (X3), pendapatan per bulan (X4), jarak (X5) terhadap permintaan objek wisata secara bersamasama. Dari hasil pengujian yang terdapat pada Tabel 1 diketahui bahwa nilai $F_{\text {hitung }}$ adalah sebesar 2,777, dengan nilai probabilitas sebesar 0,022.Dengan nilai $F_{\text {tabel }}(\alpha=5 \%$, dan $d f=94)=2,311$, maka nilai $F_{\text {hitung }}>$ $F_{\text {tabel, }}$ atau 2,777 >2,311; dan probabilitas 0,022< 0,05 . Dari pengujian ini diperoleh kesimpulan Ho ditolak dan $\mathrm{Ha}$ diterima, atau variabel bebas berpengaruh signifikan secara bersama-sama terhadap variabel terikat. Daerah penerimaan $F$ dapat dilihat pada kurva berikut. 


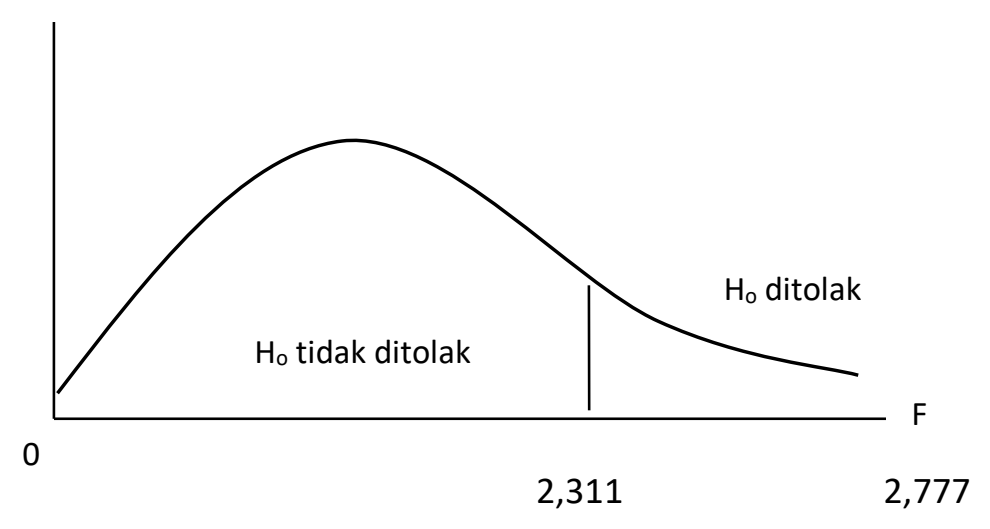

Gambar 1. Kurva Uji F

$3 \mathrm{Ujit}$

Hasil uji $\mathrm{t}$ dapat dilihat pada Tabel 1. sebelumnya. Berikut uraian dari hasil uji t:

a. Pengaruh Biaya Perjalanan ke Pantai Glagah terhadap Permintaan Wisata Pantai Glagah

Tabel 1 di atas juga menunjukkan bahwa nilai thitung variabel biaya perjalanan ke Pantai GlagahX1 adalah sebesar -2,164 dengan nilai signifikansi 0,033 , sedangkan nilai tabel dari tabel $t$ adalah 1,661. Dengan demikian diketahui bahwa thitung $<-$ ttabel; $^{2}-2,164<-1,661$, sehingga Ho ditolak dan Ha diterima. Hal ini dapat diartikan bahwa variabel bebas biaya perjalanan ke Pantai Glagah $\mathrm{X} 1$ berpengaruh secara signifikan terhadap variabel terikat $Y$, atau biaya perjalanan ke Pantai Glagah berpengaruh signifikan terhadap permintaan objek wisataPantai Glagah.

b. Pengaruh Biaya Perjalanan ke Objek Wisata Lain terhadap Permintaan Wisata Pantai Glagah

Dari Tabel 1 sebelumnya dapat dilihat bahwa nilai thitung variabel biaya perjalanan ke obyek wisata lain X2 adalah sebesar $-0,561$ dengan nilai signifikansi 0,576 , dan nilai tabel dari tabel $t$ adalah 1,661. Dengan demikian diketahui bahwa -thitung $>$-tabel; $-0,561>-1,661$, sehingga Ho diterima dan Ha ditolak. Hal ini dapat diartikan bahwa variabel bebas biaya perjalanan ke obyek wisata lain $\mathrm{X} 2$ tidak berpengaruh secara signifikan terhadap variabel terikat $\mathrm{Y}$, atau biaya perjalanan ke obyek wisata lain tidak berpengaruh signifikan terhadap permintaan objek wisata Pantai Glagah.

c. Pengaruh Umur terhadap Permintaan Wisata Pantai Glagah

Dari Tabel 1 sebelumnya juga dapat dilihat bahwa nilai thitung variabel harga barang subtitusi minyak tanah $\mathrm{X} 3$ adalah sebesar 0,408 dengan nilai signifikansi 0,648 , dan nilai tabel dari tabel $t$ adalah 1,661. Dengan demikian diketahui bahwa thitung $<$ tabel; $0,408<1,661$, sehingga Ho diterima dan Ha ditolak. Hal ini dapat diartikan bahwa variabel bebas umur X3 tidak berpengaruh secara signifikan terhadap variabel terikat $\mathrm{Y}$, atau umur tidak berpengaruh signifikan terhadap permintaan objek wisata Pantai Glagah.

d. Pengaruh Pendapatan Per Bulan terhadap Permintaan Wisata Pantai Glagah

Dari Tabel 1 sebelumnya juga dapat dilihat bahwa nilai thitung variabel pendapatan per bulanX3 adalah sebesar $-0,664$ dengan nilai signifikansi 0,508 , dan nilai tabel dari tabel $t$ adalah 1,661 . Dengan demikian diketahui bahwa -thitung $>$-tabel; $0,664>-1,661$, sehingga Ho diterima dan $\mathrm{Ha}$ ditolak. Hal ini dapat diartikan bahwa variabel bebas pendapatan per bulan X3 tidak berpengaruh secara signifikan terhadap variabel terikat $\mathrm{Y}$, atau pendapaan per bulan tidak berpengaruh signifikan terhadap permintaan objek wisata Pantai Glagah.

e. Pengaruh Jarak terhadap Permintaan Wisata Pantai Glagah

Dari Tabel 1 sebelumnya juga dapat dilihat bahwa nilai thitung variabel jarak X3 adalah sebesar 0,225 dengan nilai signifikansi 0,823 , dan nilai ttabel dari tabel $t$ adalah 1,661. Dengan demikian diketahui bahwa thitung $<$ tabel; 0,225 $<1,661$, sehingga Ho diterima dan Ha ditolak. Hal ini dapat diartikan bahwa variabel bebas jarak X3 tidak berpengaruh secara signifikan terhadap variabel terikat $\mathrm{Y}$, atau jarak tidak berpengaruh signifikan terhadap permintaan objek wisata Pantai Glagah.

\section{Perhitungan Valuasi Ekonomi}

Dalam penelitian ini untuk menghitung valuasi ekonomi digunakan metode biaya perjalanan individu (Individual Travel Cost Method), yaitu dengan menghitung nilai surplus konsumen tiap individu pertahun.

Untuk menghasilkan surplus konsumen perindividu pertahun digunakan perhitungan integral terbatas. Dari hasil perhitungan diperoleh surplus konsumen per individu per tahun adalah Rp 390.456,dimana pengunjung yang datang ke objek wisata Pantai Glagah rata-rata telah berkunjung 1 kali ke tempat tersebut. Sehingga diketahui bahwa kelebihan (surplus) yang dinikmati konsumen karena kemampuannya untuk membayar melebihi permintaan aktualnya dimana nilai 
aktual tersebut untuk individu serbesar Rp 88.030,- dan surplus konsumen setahun yang didapat sebesar Rp 390.456,- per individu per tahun.

Surplus konsumen sebesar Rp 390.456,- per individu per satu kali kunjungan menunjukkan bahwa keuntungan yang diperoleh konsumen yaitu pengunjung Objek Wisata Pantai Glagah, masih jauh di atas harga pengeluaran rata-rata sebesar $\mathrm{Rp} 88.030$,- per satu kali kunjungan. Hal ini berarti Objek Wisata Pantai Glagah memberikan manfaat yang lebih besar dari apa yang ditawarkan terhadap para pengunjung dan juga dari biaya yang yang harus mereka keluarkan agar dapat menikmati Pantai Glagah. Untuk memperoleh nilai total ekonomi, maka nilai surplus konsumen per individu per tahun sebesar Rp. 390.456,- dikalikan dengan jumlah pengunjung kunjungan, sehingga diperoleh nilai total ekonomi objek wisata Pantai Glagah.

\section{Perhitungan Valuasi Ekonomi Interpretasi Hasil}

Berdasarkan hasil analisis regresi diketahui variabel yang paling dominan mempengaruhi permintaan objek wisata, yaitu variabel biaya perjalanan ke Pantai Glagah (X1). Hal ini diketahui dari nilai standardized coefficients yang paling besar pada variabel $X 2$, yaitu $-0,314$. Koefisien setiap paramater pada persamaan regresi tersebut dapat ditaksirkan sebagai berikut.

1. $\beta 0=2,200$

Besarnya konstanta 2,200 menunjukkan bahwa jumlah permintaan objek wisata adalah sebesar 2,200 jika variabel biaya perjalanan ke Pantai Glagah (X1), biaya perjalanan ke Obyek Wisata Lain (X2), umur (X3), pendapatan per bulan (X4), jarak (X5) adalah 0 (nol).

2. $\beta 1=-0,143$

Koefisien regresi dengan tanda negatif menunjukkan adanya hubungan tidak searah, yaitu apabila variabel biaya perjalanan ke Pantai Glagah naik sebesar $1 \%$ maka permintaan objek wisata turun sebesar $0,143 \%$. Sebaliknya, apabila variabel biaya perjalanan ke Pantai Glagah turun sebesar 1\% maka mengakibatkan permintaan objek wisata naik sebesar $0,143 \%$ dengan asumsi variabel lainnya adalah konstan.

3. $\beta 2=-0,016$

Koefisien regresi dengan tanda negatif ini menunjukkan adanya hubungan yang tidak searah, yaitu apabila variabel biaya perjalanan ke obyek wisata lain bertambah sebesar $1 \%$ maka permintaan objek wisata turun sebesar $0,468 \%$. Sebaliknya, apabila variabel biaya perjalanan ke obyek wisata lain turun sebesar 1\% maka mengakibatkan permintaan objek wisata naik sebesar 0, 016\% dengan asumsi variabel lainnya adalah konstan.

4. $\beta 3=0,062$

Koefisien regresi dengan tanda positif menunjukkan adanya hubungan yang searah, yaitu apabila variabel umur naik sebesar $1 \%$ maka permintaan objek wisata naik sebesar $0,062 \%$. Sebaliknya, apabila variabel umur naik sebesar $1 \%$ maka mengakibatkan permintaan objek wisata naik sebesar 0,062\% dengan asumsi variabel lainnya bersifat konstan.

5. $\beta 4=-0,039$

Koefisien regresi dengan tanda negatif menunjukkan adanya hubungan yang tidak searah, yaitu apabila variabel pendapatan per bulan naik sebesar $1 \%$ maka permintaan objek wisata turun sebesar $0,039 \%$. Sebaliknya, apabila variabel pendapatan per bulan turun sebesar 1\% maka mengakibatkan permintaan objek wisata naik sebesar $0,039 \%$ dengan asumsi variabel lainnya bersifat konstan.

6. $\beta 5=0,012$

Koefisien regresi dengan tanda positif menunjukkan adanya hubungan yang searah, yaitu apabila variabel jarak naik sebesar $1 \%$ maka permintaan objek wisata naik sebesar $0,012 \%$. Sebaliknya, apabila variabel jarak naik sebesar $1 \%$ maka mengakibatkan permintaan objek wisata naik sebesar $0,012 \%$ dengan asumsi variabel lainnya bersifat konstan.

\section{SIMPULAN}

Kesimpulan yang diperoleh berdasarkan hasil penelitian ini adalah sebagai berikut:

1. Hasil penelitian menunjukkan bahwa biaya perjalanan ke objek wisata Pantai Glagah berpengaruh negatif dan signifikan terhadap permintaan wisata Pantai Glagah. Hal ini dapat diketahui dari nilai koefisien $\beta 1$ sebesar $-0,143$, dan nilai -thitung <-ttabel; -2,164<-1,661. Dengan demikian, hipotesis 1 penelitian dapat diterima.

2. Hasil penelitian menunjukkan bahwa biaya perjalanan ke objek wisata lain berpengaruh negatif namun tidak signifikan terhadap permintaan wisata Pantai Glagah. Hal ini dapat diketahui dari nilai koefisien $\beta 2$ sebesar -0,016, dan -thitung > -ttabel; $0,561<1,661$. Dengan demikian, hipotesis 2 penelitian tidak dapat diterima.

3. Hasil penelitian menunjukkan bahwa umur berpengaruh positif dan tidak signifikan terhadap permintaan wisata Pantai Glagah. Hal ini dapat diketahui dari nilai koefisien $\beta 3$ sebesar 0,062 , nilai thitung < ttabel; 0,408 < 1,661. Dengan demikian, hipotesis 3 penelitian tidak dapat diterima.

4. Hasil penelitian menunjukkan bahwa pendapatan per bulan berpengaruh negatif tetapi tidak signifikan terhadap permintaan wisata Pantai Glagah. Hal ini dapat diketahui dari nilai koefisien $\beta 1$ sebesar $-0,039$, dan nilai -thitung > -ttabel; -0,664 >-1,661. Dengan demikian, hipotesis 4 penelitian tidak dapat diterima.

5. Hasil penelitian menunjukkan bahwa jarak berpengaruh positif dan tidak signifikan terhadap permintaan wisata Pantai Glagah. Hal ini dapat diketahui dari nilai koefisien $\beta 5$ sebesar 0,012 , dan nilai thitung < ttabel; $0,225<1,661$. Dengan demikian, hipotesis 5 penelitian tidak dapat diterima.

6. Surplus konsumen sebesar Rp Rp 390.456,- per individu per satu kali kunjungan menunjukkan bahwa keuntungan yang diperoleh oleh konsumen yaitu pengunjung Pantai Glagah masih jauh di atas harga rata-rata pengeluaran perjalanan yaitu $\mathrm{Rp} 88.030$,- 
per kunjungan. Hal ini berarti objek wisata Pantai Glagah memberikan manfaat yang lebih besar dari apa yang ditawarkan kepada para pengunjung dan juga dari biaya yang harus mereka keluarkan agar dapat menikmati Pantai Glagah. 1

\section{DAFTAR PUSTAKA}

Azis, Iwan J., dkk. (2010). Pembangunan Berkelanjutan: Peran dan Kontribusi Emil Salim. Jakarta: KPG.

Azzahra, Fatimah \& Sujali. (2013). Pengembangan Pariwisata Alam Kawasan Ciwidey di Kabupaten Bandung. Jurnal Bumi Indonesia, Volume 2, Nomor 2, Tahun 2013: 267-276.

Charaf, Karim \& Rahmouni, Ahmed Fath-Allah. (2014). Using Importance Performance Analysis to Evaluate the Satisfaction of Activity-Based Costing Adopters. Accounting and Management Information Systems Vol. 13, No. 4: 665-685.

Darsoprayitno, Soewarno. (2012). Ekologi Pariwisata: Tata Laksana Pengelolaan Obyek dan Daya Tarik Wisata. Jakarta: Angkasa.

De Nisco, Alessandro; Riviezzo, Angelo; \& Napolitano, Maria Rosaria. (2015). Using ImportancePerformance Analysis in Evaluating Tourist Satisfaction, The Case of Campania. European Journal of Tourism Research 10: 64-75.

Hananto, Akhyari. (2016). Good News from Indonesia: Beragam Prestasi Anak Bangsa di Dunia. Yogyakarta: Galang Pustaka.

Indriantoro, Nur \& Supomo, Bambang. (2008). Metode Penelitian Bisnis. Yogyakarta: BPFE UGM.

Kotler, Philip \& K.K. Keller. (2013). Marketing Manajemen, 14 edition, Upper Saddle River N.J. : Pearson Education. Inc..

Mulyana, D. \& Rakhmat, J. (2009). Komunikasi Antar Budaya: Panduan Berkomunikasi Dengan Orangorang Berbeda Budaya. Bandung: Remaja Rosdakarya.

Pendit, Nyoman S. (2006). IImu Pariwisata Sebuah Pengantar Perdana. Jakarta: Pradnya Paramita.

Republik Indonesia. (2009). Undang-undang Nomor 10 Tahun 2009 tentang Kepariwisataan. Jakarta: Sekertaris Negara.

Spillane, James J. (2006). Ekonomi Pariwisata Sejarah dan Prospeknya. Yogyakarta: Kanisius.

Sugiantoro, Ronny. (2005). Pariwisata: Antara Obsesi dan Realita. Yogyakarta: Adicita Karya Nusa.

Suwantoro, Gamal. (2004). Dasar-Dasar Pariwisata. Yogyakarta: Andi.

Utama, I Gusti Bagus Rai. (2016). Pengantar Industri Pariwisata, Tantangan dan Peluang Bisnis Kreatif. Yogyakarta: Deepublish.

Wade, Derek J. \& Eagles, Paul W. J. (2003). The Use of Importance-Performance Analysis and Market Segmentation for Tourism Management in Parks and Protected Areas: An Application to Tanzania's National Parks. Journal Of Ecotourism, Vol. 2, No. 3, 2003: 196-212.

Wardiyanta. (2010). Metode Penelitian Pariwisata. Yogyakarta: Penerbit: Andi.

Wong, Meng Seng; Hideki, Nishimoto; \& George, Philip. (2011). The Use of Importance-Performance
Analysis (IPA) in Evaluating Japan's EGovernment Services. Journal of Theoretical and Applied Electronic Commerce Research, Vol 6, Issue 2, August 2011: 17-30.

Yoeti, Oka A. (2008). Ekonomi Pariwisata. Jakarta: Kompas. 